\title{
The role of proprotein convertase subtilisin-kexin type 9 (PCSK9) in the vascular aging process - is there a link?
}

\author{
Malwina K. Grobelna ${ }^{1}$, Ewa Strauss ${ }^{1,2}$, Zbigniew Krasiński ${ }^{1}$ \\ ${ }^{1}$ Department of Vascular, Endovascular Surgery, Angiology and Phlebology Poznan University of Medical \\ Sciences, Poznan, Poland \\ ${ }^{2}$ Institute of Human Genetics, Polish Academy of Sciences, Poznan Poland
}

Kardiochir Torakochir Pol 2019; 16 (3): 128-132

\begin{abstract}
Lately there are many new, promising low-density lipoprotein cholesterol reducing therapies with PCSK9 inhibitors. We performed selected sampling of the publications in PubMed and made a review according to selected keywords. It summarizes the effect of PCSK9 on vascular aging, directly associated with lipid and glucose metabolism, chronic inflammation, atherosclerosis and hypertension. Serum level of PCSK9 is different in patients affected by certain illnesses (whose risk increases with age) than in healthy individuals. The same could be observed in the case of chronic inflammation. In this review we summarize what is known about the role PCSK9 in human metabolism and how this could affect the vascular aging process. Based on the available sources, we prove that PCSK9 is involved in many biochemical pathways associated with vascular aging. In the future, treatments using PCSK9 inhibition may not only reduce the cardiovascular risk but also slow down this process.
\end{abstract}

Key words: vascular aging, PCSK9, atherosclerosis, inflammation, cholesterol.

\section{Introduction}

Atherosclerosis and related cardiovascular diseases are among the most common human diseases worldwide [1]. This degenerative process of the blood vessel wall may develop and coexist in almost all vascular beds; therefore, atherosclerosis is referred to as a systemic disease. Development of atherosclerosis is closely related to the aging process of the human body. Vascular aging is a term specific for blood vessels, describing changes in the properties of the vascular wall, specifically mechanical and structural. It is characterized by the loss of arterial wall elasticity and arterial wall thickening which results in luminal dilation

\section{Streszczenie}

Ostatnio pojawiła się nowa metoda redukcji stężenia cholesterolu LDL z wykorzystaniem inhibitorów PCSK9. Na podstawie przeglądu piśmiennictwa dostępnego $w$ bazie PubMed podsumowano wiedzę na temat związku białka PCSK9 z procesami starzenia naczyń krwionośnych. Procesy te są bezpośrednio powiązane z metabolizmem lipidów i glukozy, przewlekłym stanem zapalnym, miażdżycą, a także nadciśnieniem tętniczym. Zebrane dane wskazują na różnice w stężeniach białka PCSK9 w osoczu między osobami zdrowymi a osobami dotkniętymi określonymi chorobami występującymi w starszym wieku. Ta sama zależność występuje w przypadku przewlekłego stanu zapalnego. W niniejszej pracy podsumowano wiedzę na temat roli PCSK9 w metabolizmie człowieka, przedstawiając szlaki biochemiczne z udziałem tego białka, które oddziałują na proces starzenia naczyń krwionośnych. Na podstawie dostępnych źródeł autorzy wskazują na istotną rolę PCSK9 w szlakach biochemicznych zaangażowanych $w$ ten proces. Przypuszcza się, że leczenie z zastosowaniem inhibicji PCSK9 będzie skutkować nie tylko zmniejszeniem ryzyka rozwoju chorób układu krążenia, lecz także spowolnieniem procesu starzenia naczyń krwionośnych.

Słowa kluczowe: starzenie naczyń krwionośnych, PCSK9, miażdżyca, stan zapalny, cholesterol.

and reduction of arterial compliance [2, 3]. The most important early marker of arterial wall damage is endothelial dysfunction, which leads to intima-media thickening and is associated with many pathophysiological mechanisms [3]. Current studies prove that proprotein convertase subtilisin/ kexin type 9 (PCSK9) takes part in many processes in the human body and its role in vascular aging could be vital.

\section{Aim}

This review highlights the impact of PCSK9 on factors responsible for vascular aging, including atherosclerosis, hyperglycaemia and pathological inflammatory response.

Address for correspondence: Malwina K. Grobelna MD, Department of Vascular, Endovascular Surgery, Angiology and Phlebology Poznan University of Medical Sciences, 1/2 Długa St, 61-848 Poznan, Poland, e-mail: malwagrobelna@gmail.com

Received: 29.08.2019, accepted: 4.09.2019 
Authors also shortly describe how PCSK9 can control human cholesterol homeostasis on molecular level.

\section{Material and methods}

A selected sampling of the publications on PubMed was conducted and a review created according to selected keywords.

\section{Results and discussion}

\section{The characteristics of PCSK9} and its various roles in human

PCSK9 was identified in 2003 by Seidah et al. [4]. In humans, the PCSK9 gene is located on chromosome 1 p32.3 and is expressed mainly in the liver, but also in the intestine, the kidney and even in the nervous system [5]. Basing on a meta-analysis study collecting over 300.000 patients, focused on nine most studied single nucleotide polymorphisms (SNPs) in the PCSK9 gene. The rs11591147 SNP has the greatest LDL cholesterol lowering potential and thus results in the threefold CV risk reduction [6]. PCSK9 regulates $L D L-C$ concentrations by acting on the $L D L$ receptors (LDLR) (Figure 1) [7] but its role in human is not limited only to cholesterol metabolism. In the nervous system, PCSK9 is involved in the differentiation of cortical neurons and might have a pro-apoptotic and protective function [8]. Its concentration in the cerebrospinal fluid in humans is at 60 times lower than in human serum [9]. According to the Reasons for Geographic and Racial Differences in Stroke (REGARDS) study, some rare polymorphisms of the PCSK 9 gene are responsible for regulation of blood pressure in Afro-Americans [10]. In 2008, Feingold et al. (2008) described how inflammation stimulates PCSK9 expression, causing increased LDLR degradation, consequently increasing serum LDL level [11]. The data also show that PCSK9 has an antiviral effect against HCV virus not only by degradation of the LDLR but also downregulation of CD81 on the surface of hepatic cells

A

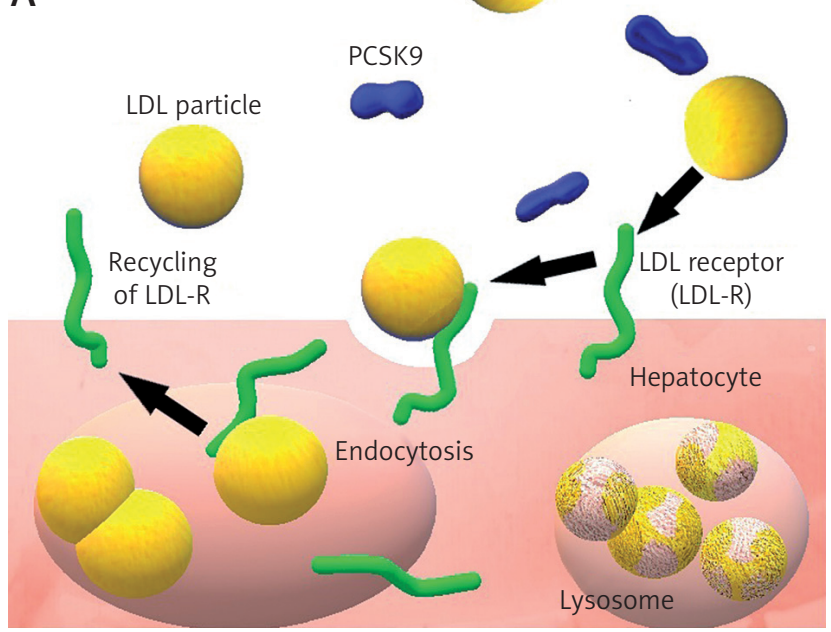

LDL particle is taken up via receptor, then degraded and the receptor recycled
- a primary HCV receptor [12, 13]. Upregulation of PCSK9 can be observed in sepsis and might impair the host immune response and survival by exacerbation of organ dysfunction and general inflammation. On the other hand, low levels of PCSK9 in septic patients seem to have a protective effect [14]. In patients suffering from stable coronary artery disease, PCSK9 levels correlate with white blood cell count [15].

\section{Factors related to PCSK9 responsible for aging of the arterial wall}

Inflammation causes endothelial dysfunction, promotes atherosclerotic plaque formation, its vulnerability and rupture [3]. There is a mechanism involving PCSK9 stimulating lectin-like oxidized low-density lipoprotein receptor-1 (LOX-1). It is a major oxidized LDL receptor located in endothelial cells, associated with endothelial dysfunction and atherosclerosis [16]. LOX-1 expression is upregulated in inflammation [17]. Thus, inflammatory state-related atherosclerosis may be aggravated by PCSK9 stimulation of LOX-1 transcription and LOX-1 stimulation of PCSK9 expression [18]. It remains to be discovered whether PCSK9 inhibitors can prevent this process by antagonizing LOX-1 expression. Interestingly, patients suffering from autoimmune diseases demonstrate increased CV risk and subclinical atherosclerosis-related problems. These diseases are associated with a chronic inflammatory process. The most common include systemic lupus erythematosus (SLE), rheumatoid arthritis (RA), antiphospholipid syndrome (AS), and systemic sclerosis (SS) [19]. For instance, patients suffering from SLE have significantly higher risk of premature atherosclerosis and increased CV risk [20]. According to Mok et al. (2011), there is a constant mortality pattern mostly due to CV events in SLE patients. In their study, the observed loss of life expectancy years in female patients was 19.7 years and 27 years in male patients [21]. Magder et al. (2012) conducted a cohort study on 1874 patients suffering from SLE, observing them for the period from April 1987 to June 2010.
B

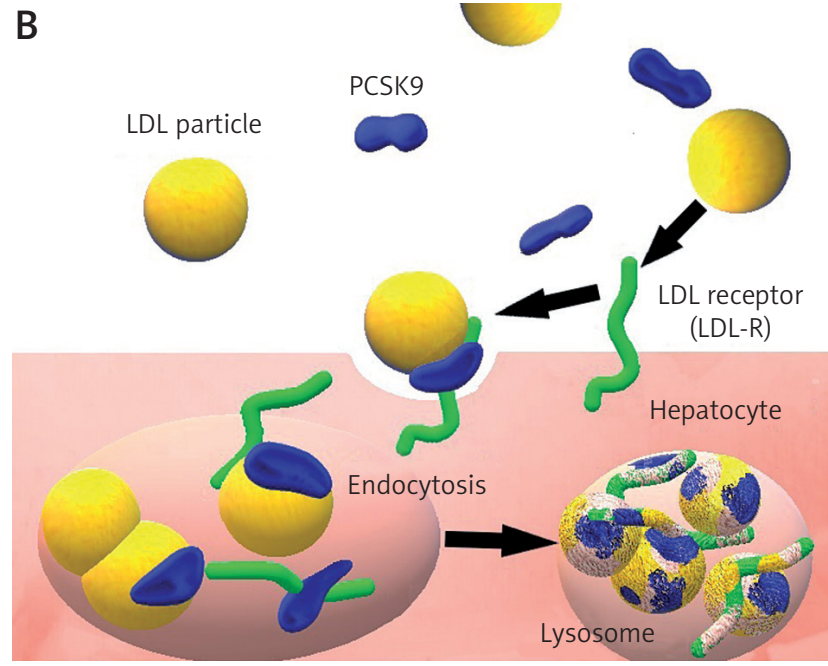

PCSK9 binds to the LDL receptor changing its conformation and enhances lysosomal degradation of the receptor

Figure 1. Degradation of the LDL receptor by PCKS9 action 
The results revealed that SLE patients have a 2.7 -fold increase in risk of acute CV events (i.e. "stroke, myocardial infarction, angina, coronary intervention, and peripheral vascular disease") relative to the expected Framingham risk score [22]. Interestingly, in SLE peripheral artery occlusive disease (PAOD) the risk is 9-fold higher relative to the general population [23]. One of the reasons for premature atherosclerosis and vascular wall aging in SLE patients is that the integrity of the arterial endothelium is damaged, either directly by binding antibodies or by deposition of autoimmune complexes [24]. The PCSK9 gene was also investigated in carriers of antiphospholipid antibodies (aPLA). Similarly to other autoimmune diseases, aPLA cause endothelial damage, and in this case, thrombosis. Comparing the aPLA carriers to a healthy control group, a relevant allelic association with the rs562556 SNP in PCSK9 was found, making the carriers more prone to thrombosis due to endothelial dysfunction [25]. There is evidence that some of the metabolic pathways of cholesterol and glycaemic control are crossed. For example, in a study conducted on 18 healthy subjects, co-regulation between the PCSK9 gene and cholesterol synthesis was tested. During a 48-hour fasting period the levels of PCSK9 in observed subjects' plasma decreased by $\sim 58 \%$, reaching the lowest point at 36 hours of fasting [26]. Moreover, a regulatory pathway of PCSK9 was recently found, which might be related to diabetes mellitus (DM). It is associated with a mechanistic target of rapamycin complex 1 (mTORC1) protein complex which can be influenced by hyperglycaemia. Stimulation of mTORC1 by insulin leads to activation of protein kinase C-delta (PKC $\delta$ ). As a result, the activity of HNF4 $\alpha$ and HNF1 $\alpha$ is inhibited, and subsequently also PCSK9 transcription [27]. Furthermore, the mTORC1 complex can be influenced by pro-inflammatory cytokines (IL-6, TNF) [28]. It is suggested that $\mathrm{PKC} \delta$ plays a role in fatty acid-induced insulin resistance. Additionally, it is one of the factors responsible for liver lipogenesis regulation [29, 30]. Hyperglycaemia and conditions related to insulin resistance stimulate collagen deposition and increase lipid infiltration and smooth muscle cell proliferation and consequently alter vasomotor tone [3]. Interestingly, a recent Mendelian randomisation study proved that PCSK9 variants lowering LDL cholesterol can increase the risk of type $2 \mathrm{DM}$. The studied patients presented high circulating fasting glucose concentration, high body weight and also increased waist-to-hip ratio [31]. To summarize, PCSK9 takes part in many systemic pathologies in which vascular wall destruction and atherosclerosis aggravation are observed.

\section{Local effect of PCSK9 on vascular wall senescence and atherosclerotic plaque}

There are some age-related pathologic mechanisms including a decrease in nitric oxide bioavailability, low-grade inflammation, increased production of reactive oxygen species (ROS) and endothelial senescence, which make the arterial wall more prone to oxidative stress [32]. With age, endothelin production is increased and smooth muscle growth promoted. Diseases such as DM or arterial hypertension $(\mathrm{AH})$ increase the cardiovascular risk and boost the process of vascular aging [3]. Apart from systemic action PCSK9 can influence the vascular wall and atherosclerotic plaque locally. Giunzioni et al. (2007) described how PCSK9 mediates the inflammatory process in atherosclerotic plaque. They observed increased infiltration of inflammatory monocytes to the plaque, which differentiates to macrophages afterward (a 32\% increase in inflammatory positive cells compared to the control tissue) [33]. The local PCSK9 is produced by endothelial cells, smooth muscle vascular cells and even macrophages in an atherosclerotic lesion [34]. There is a possibility that PCSK9 secreted by intraplaque macrophages can influence the monocytes to infiltrate the atherosclerotic lesion independently of its action in serum or the arterial wall [34]. The influence of local PCSK9 on foam cell receptors in the plaque is still unknown. Clinically important is the fact that composition of the plaque plays a more important role than its size regarding risk of rupture and thrombogenicity [34]. Another study described the role of PCSK9 in maturation of oxidized LDL-induced dendritic cell and T cell activation in atherosclerotic plaque. This proved the direct effect of PCSK9 on atherosclerotic plaque independently of its action on systemic LDL [35]. One of the conducted studies investigated mice kept on a cholesterol-rich diet causing hypercholesterolemia. Its aim was to evaluate the effect of anti-PCSK9 monoclonal antibodies on the atherosclerotic lesion. Not only a reduction in monocyte recruitment as the inflammatory response was observed, but also improved lesion morphology [36]. All this suggests that PCSK9 strongly influences some of the critical components of the atherosclerotic lesion formation process. This may suggest an extra beneficial effect of anti-PCSK9 therapy directly on the atherosclerotic plaque, apart from an LDL-lowering effect. Another process responsible for vascular aging is related to the reactive oxygen species (ROS). They can modulate cellular signalling pathways, inducing changes in the cellular phenotype. This particular ROS function is responsible for vascular remodelling processes. It includes modulating cellular cytoskeletal properties, cell proliferation, migration, and death and altering the extracellular matrix (ECM). All these properties of the vascular wall are linked to its mechanical characteristics and change during the vascular senescence process [37]. In a study conducted by Ding et al., low shear stress via ROS enhanced PCSK9 expression. Both vascular endothelial cells and vascular smooth muscle cells were investigated. It was found that ROS regulated PCSK9 expression. The PCSK9-ROS interaction may be important in vascular aging and atherosclerosis propagation [38]. Within the atherosclerotic plaque, PCSK9 is present and released by smooth muscle cells (SMCs). The inflammatory cytokines released from macrophages induce the proliferation and migration of media SMCs. This causes thickening of the vessel wall and is considered to be one of the agerelated impairments, a part of the vascular aging process [39]. In 2018 evidence for a direct pro-inflammatory effect 
of PCSK9 on macrophages was provided, mainly LDLR dependent [40]. Furthermore, silencing of PCSK9 gene expression results in suppression of macrophages' inflammatory response to oxidized LDL, which demonstrates PCSK9's still not fully understood role in inflammation [41].

\section{Conclusions}

Based on experimental data available to date, it can be concluded that PCSK9 is involved in many biochemical pathways associated with the vascular aging process. Progression of this process is influenced by hypercholesterolemia, hypertension, oxidative stress, inflammation, and hyperglycaemia. Diseases mentioned in this review are established factors associated with high PCSK9 serum levels, which partially explains why intensified atherosclerosis can be observed in affected patients. Keeping in mind the complex role of PCSK9, especially in lipid and glucose metabolism, inflammation and its association with atherosclerotic plaque composition, it can be expected that there will be new clinical indications for an anti-PCSK9 therapy apart from lowering serum LDL-C. Treatments using PCSK9 inhibition may not only contribute to cardiovascular risk reduction, but also alter the composition of atherosclerotic plaque and slow down the process of vascular aging.

\section{Disclosure}

The authors report no conflict of interest.

\section{References}

1. Fowkes FG, Rudan D, Rudan I, Aboyans V, Denenberg JO, McDermott MM, Norman PE, Sampson UK, Williams LJ, Mensah GA, Criqui MH. Comparison of global estimates of prevalence and risk factors for peripheral artery disease in 2000 and 2010: a systematic review and analysis. Lancet 2013; 382: 1329-1340,

2. Jani B, Rajkumar C. Ageing and vascular aging, Postgrad Med J 2006; 82: 357-362.

3. Nilsson PM, Olsen MH, Laurent S. Early Vascular Aging (EVA). New Directions in Cardiovascular Protection. Elsevier 2015; 137-145, 157-167, 147-156, 139-145.

4. Seidah NG, Benjannet S, Wickham L, Marcinkiewicz J, Jasmin SB, Stifani S, Basak A, Prat A, Chretien M. The secretory proprotein convertase neural apoptosis-regulated convertase 1 (NARC-1): liver regeneration and neuronal differentiation. Proc Natl Acad Sci USA 2003; 100: 928-933.

5. Seidah NG, Prat A. The biolo.gy and therapeutic targeting of the proprotein convertases. Nat Rev Drug Discov 2012; 11: 367-383

6. Ference BA, Yoo W, Alesh I, Mahajan N, Mirowska KK, Mewada A, Kahn J, Afonso L, Williams KA Sr, Flack JM. Effect of long-term exposure to lower lowdensity lipoprotein cholesterol beginning early in life on the risk of coronary heart disease: a Mendelian randomization analysis. J Am Coll Cardiol 2012; 60: 2631-2639.

7. Lo Surdo P, Bottomley MJ, Calzetta A, Settembre EC, Cirillo A, Pandit S, Ni YG, Hubbard B, Sitlani A, Carfí A. Mechanistic implications for LDL receptor degradation from the PCSK9/LDLR structure at neutral pH. EMBO Rep 2011; 12: 1300-1305.

8. Seidah NG, Benjannet S, Wickham L, Marcinkiewicz J, Jasmin SB, Stifani S, Basak A, Prat A, Chretien M. The secretory proprotein convertase neural apoptosis-regulated convertase 1 (NARC-1): liver regeneration and neuronal differentiation. Proc Natl Acad Sci USA 2003; 100: 928-933.

9. Chen YQ, Troutt JS, Konrad RJ. PCSK9 is present in human cerebrospinal fluid and is maintained at remarkably constant concentrations throughout the day. Lipids 2014; 49: 445-455.

10. Tran NT, Aslibekyan S, Tiwari HK, Zhi D, Sung YJ, Hunt SC, Rao DC, Broeckel U, Judd SE, Muntner P, Kent ST, Arnett DK, Irvin MR. PCSK9 variation and asso- ciation with blood pressure in African Americans: preliminary findings from the HyperGEN and REGARDS studies. Front Genet 2015; 6: 136

11. Feingold KR, Moser AH, Shigenaga JK, Patzek SM, Grunfeld C. Inflammation stimulates the expression of PCSK9. Biochem Biophys Res Commun 2008; 374: 341-344.

12. Khademi F, Momtazi-Borojeni AA, Reiner Ž, Banach M, Al-Rasadi KA, Sahebkar A. PCSK9, and infection: a potentially useful or dangerous association? J Cell Physiol 2018; 233: 2920-2927.

13. Labonté P, Begley S, Guévin C, Asselin MC, Nassoury N, Mayer G, Prat A, Seidah NG. PCSK9 impedes hepatitis $C$ virus infection in vitro and modulates liver CD81 expression. Hepatology 2009; 50: 17-24.

14. Paciullo F, Fallarino F, Bianconi V, Mannarino MR, Sahebkar A, Pirro M. PCSK9 at the crossroad of cholesterol metabolism and immune function during infections. J Cell Physiol 2017; 232: 2330-2338.

15. Li S, Guo YL, Xu RX, Zhang Y, Zhu CG, Sun J, Qing P, Wu NQ, Jiang LX, Li JJ. Association of plasma PCSK9 levels with white blood cell count and its subsets in patients with stable coronary artery disease. Atherosclerosis 2014; 234: 441-445.

16. Chen M, Masaki T, Sawamura T. LOX-1, the receptor for oxidized low-density lipoprotein identified from endothelial cells: implications in endothelial dysfunction and atherosclerosis. Pharmacol Ther 2002; 95: 89-100.

17. Shapiro MD, Fazio S. PCSK9 and atherosclerosis - lipids and beyond. J Atheroscler Thromb 2017; 24: 462-472.

18. Ding Z, Liu S, Wang X, Deng X, Fan Y, Shahanawaz J, Shmookler Reis RJ, Varughese KI, Sawamura T, Mehta JL. Cross-talk between LOX-1 and PCSK9 in vascular tissues. Cardiovasc Res 2015; 107: 556-567.

19. Zinger H, Sherer $\mathrm{Y}$, Shoenfeld $\mathrm{Y}$. Atherosclerosis in autoimmune rheumatic diseases-mechanisms and clinical findings. Clin Rev Allergy Immunol 2009; 37: 20-28.

20. Teixeira V, Tam LS. Novel insights in systemic lupus erythematosus and atherosclerosis. Front Med 2017; 4: 262.

21. Mok CC, Kwok CL, Ho LY, Chan PT, Yip SF. Life expectancy, standardized mortality ratios, and causes of death in six rheumatic diseases in Hong Kong, China. Arthritis Rheum 2011; 63: 1182-1189.

22. Magder LS, Petri M. Incidence of and risk factors for adverse cardiovascular events among patients with systemic lupus erythematosus. Am J Epidemiol 2012; 176: 708-719.

23. Chuang YW, Yu MC, Lin CL, Yu TM, Shu KH, Kao CH. Risk of peripheral arterial occlusive disease in patients with systemic lupus erythematosus: a nationwide population-based cohort study. Medicine 2015; 94: e2121.

24. Prechl J, Czirják L. The endothelial deprotection hypothesis for lupus pathogenesis: the dual role of $\mathrm{Clq}$ as a mediator of clearance and regulator of endothelial permeability. F1000Res 2015; 4: 24

25. Fullaondo A, Villar I, Ruiz-Irastorza G, Zubiaga AM, Estonba A. LDLR and PCSK9 are associated with the presence of antiphospholipid antibodies and the development of thrombosis in aPLA carriers. PLoS One 2016; 11: e0146990.

26. Browning JD, Horton JD. Fasting reduces plasma proprotein convertase, subtilisin/kexin type 9 and cholesterol biosynthesis in humans. J Lipid Res 2010; 51: 3359-3363.

27. Ai D, Chen C, Han S, Ganda A, Murphy AJ, Haeusler R, Thorp E, Accili D, Horton JD, Tall AR. Regulation of hepatic LDL receptors by mTORC1 and PCSK9 in mice. J Clin Invest 2012; 122: 1262-1270.

28. Zhang Y, Ma KL, Ruan XZ, Liu BC. Dysregulation of the low-density lipoprotein receptor pathway is involved in lipid disorder mediated organ injury. Int J Biol Sci 2016; 12: 569-579.

29. Lam TK, Yoshii H, Haber CA, Bogdanovic E, Lam L, Fantus IG, Giacca A. Free fatty acid-induced hepatic insulin resistance: a potential role for protein kinase C-delta. Am J Physiol Endocrinol Metab 2002; 283: E682-E691.

30. Frangioudakis G, Burchfield JG, Narasimhan S, Cooney GJ, Leitges M, Biden TJ, Schmitz-Peiffer C. Diverse roles for protein kinase $C$ delta and protein kinase $C$ epsilon in the generation of high-fat-diet-induced glucose intolerance in mice: regulation of lipogenesis by protein kinase C delta. Diabetologia 2009; 52: 2616-2620.

31. Schmidt AF, Swerdlow DI, Holmes MV, Patel RS, Fairhurst-Hunter Z, Lyall DM, Hartwig FP, Horta BL, Hyppönen E, Power C, Moldovan M, van Iperen E, Hov ingh GK, Demuth I, Norman K, Steinhagen-Thiessen E, Demuth J, Bertram L, Liu T, Coassin S, Willeit J, Kiechl S, Willeit K, Mason D, Wright J, Morris R, Wanamethee G, Whincup P, Ben-Shlomo Y, McLachlan S, Price JF, Kivimaki M, Welch C, Sanchez-Galvez A, Marques-Vidal P, Nicolaides A, Panayiotou AG, Onland-Moret NC, van der Schouw YT, Matullo G, Fiorito G, Guarrera S, Sacerdote C, Wareham NJ, Langenberg C, Scott R, Luan J, Bobak M, Maly 
utina S, Pająk A, Kubinova R, Tamosiunas A, Pikhart H, Husemoen LL, Grarup N, Pedersen O, Hansen T, Linneberg A, Simonsen KS, Cooper J, Humphries SE, Brilliant M, Kitchner T, Hakonarson H, Carrell DS, McCarty CA, Kirchner HL, Larson EB, Crosslin DR, de Andrade M, Roden DM, Denny JC, Carty C, Hancock S, Attia J, Holliday E, O'Donnell M, Yusuf S, Chong M, Pare G, van der Harst P, Said MA, Eppinga RN, Verweij N, Snieder H; LifeLines Cohort study group, Christen T, Mook-Kanamori DO, Gustafsson S, Lind L, Ingelsson E, Pazoki R, Franco O, Hofman A, Uitterlinden A, Dehghan A, Teumer A, Baumeister S, Dörr M, Lerch MM, Völker U, Völzke H, Ward J, Pell JP, Smith DJ, Meade T, Maitland-van der Zee AH, Baranova EV, Young R, Ford I, Campbell A, Padmanabhan S, Bots ML, Grobbee DE, Froguel P, Thuillier D, Balkau B, Bonnefond A, Cariou B, Smart M, Bao Y, Kumari M, Mahajan A, Ridker PM, Chasman DI, Reiner AP, Lange LA, Ritchie MD, Asselbergs FW, Casas JP, Keating BJ, Preiss D, Hingorani AD; UCLEB consortium, Sattar N. PCSK9 genetic variants and risk of type 2 diabetes: a mendelian randomisation study. Lancet Diabetes Endocrinol 2017; 5: 97-105.

32. McVeigh GE, Alen PB, Morgan DR, Hanratty CG, Silke B. Nitric oxide modulation of blood vessel tone identified by arterial waveform analysis. Clin Sci 2001; 100: 387-393.

33. Giunzioni I, Tavori H, Covarrubias R, Major AS, Ding L, Zhang Y, DeVay RM, Hong L, Fan D, Predazzi IM, Rashid S, Linton MF, Fazio S. Local effects of human PCSK9 on the atherosclerotic lesion. J Pathol 2016; 238: 52-62.

34. Shah PK. Inflammation and plaque vulnerability. Cardiovasc Drugs Ther 2009; 23: 31-40.
35. Liu A, Frostegård J PCSK9 plays a novel immunological role in oxidized LDLinduced dendritic cell maturation and activation of T cells from human blood and atherosclerotic plaque. J Intern Med 2018 doi: 10.1111/joim.12758.

36. Kuhnast S, van der Hoorn JW, Pieterman EJ, van den Hoek AM, Sasiela WJ, Gusarova V, Peyman A, Schäfer HL, Schwahn U, Jukema JW, Princen HM. Alirocumab inhibits atherosclerosis, enhances the plaque morphology, and enhances the effects of a statin. J Lipid Res 2014; 55: 2103-2112.

37. Staiculescu MC, Foote C, Meininger GA, Martinez-lemus LA. The role of re active oxygen species in microvascular remodeling. Int J Mol Sci 2014; 15: 23792-23835.

38. Ding Z, Liu S, Wang X, Deng X, Fan Y, Sun C, Wang Y, Mehta JL. Hemodynamic shear stress via ROS modulates PCSK9 expression in human vascular endothelial and smooth muscle cells and along the mouse aorta. Antioxid Redox Signal 2015; 22: 760-771.

39. Xu X, Wang B, Ren C, Hu J, Greenberg DA, Chen T, Xie L, Jin K. Age-related impairment of vascular structure and functions. Aging Dis 2017; 8: 590-610.

40. Ricci C, Ruscica M, Camera M, Rossetti L, Macchi C, Colciago A, Zanotti I, Lupo MG, Adorni MP, Cicero AFG, Fogacci F, Corsini A, Ferri N. PCSK9 induces a pro-inflammatory response in macrophages. Sci Rep 2018; 8: 2267.

41. Tang Z, Jiang L, Peng J, Ren Z, Wei D, Wu C, Pan L, Jiang Z, Liu L. PCSK9 siRNA suppresses the inflammatory response induced by oxLDL through inhibition of NF-kappaB activation in THP-1-derived macrophages. Int J Mol Med 2012; 30: 931-938. 